\title{
Stock market driven acquisitions
}

\section{Citation}

Shleifer, Andrei, and Robert W. Vishny. 2003. Stock Market Driven Acquisitions. Journal of Financial Economics 70, no. 3: 295-311. doi:10.1016/s0304-405x(03)00211-3.

\section{Published Version}

doi:10.1016/S0304-405X(03)00211-3

\section{Permanent link}

http://nrs.harvard.edu/urn-3:HUL.InstRepos:30748164

\section{Terms of Use}

This article was downloaded from Harvard University's DASH repository, and is made available under the terms and conditions applicable to Other Posted Material, as set forth at http:// nrs.harvard.edu/urn-3:HUL.InstRepos:dash.current.terms-of-use\#LAA

\section{Share Your Story}

The Harvard community has made this article openly available.

Please share how this access benefits you. Submit a story.

Accessibility 
Journal of Financial Economics 00 (2003) 000-000

\title{
Stock market driven acquisitions
}

\author{
Andrei Shleifer ${ }^{\mathrm{a}^{*}}$, Robert W. Vishny $^{\mathrm{b}}$ \\ ${ }^{a}$ Harvard University, Department of Economics, Cambridge, MA 02138, USA \\ ${ }^{b}$ University of Chicago, Graduate School of Business, 1101 East 58th Street, Chicago, IL 60637, USA
}

(Received 24 June 2002; accepted 1 December 2002)

\begin{abstract}
We present a model of mergers and acquisitions based on stock market misvaluations of the combining firms. The key ingredients of the model are the relative valuations of the merging firms and the market's perception of the synergies from the combination. The model explains who acquires whom, the choice of the medium of payment, the valuation consequences of mergers, and merger waves. The model is consistent with available empirical findings about characteristics and returns of merging firms, and yields new predictions as well.
\end{abstract}

JEL classification: G34

Keywords: Takeover, Synergy, Merger

We are grateful to Malcolm Baker, Amar Bhide, Gene D’Avolio, John Friedman, Robin Greenwood, Michael Jensen, Steven Kaplan, Rafael La Porta, Mark Mitchell, Raghu Rajan, Antoinette Schoar, Jeremy Stein, René Stulz, Luigi Zingales, students in Stein's Economics 2725, two anonymous referees, and especially Jeffrey Wurgler for helpful comments, and to the National Science Foundation for financial support of this research.

*Contact information: Andrei Shleifer, Harvard University, Department of Economics, Cambridge, MA $02138,617-495-5046$

E-mail: ashleifer@harvard.edu

0304-405X/02/ \$ see front matter (C) 2003 Published by Elsevier Science B.V. All rights reserved 


\section{Introduction}

In the late 1990s, the U.S. and world economies experienced a large wave of mergers and acquisitions. Most of these deals were for stock, and the acquirers were typically in the same industry as the targets (Andrade et al., 2001). This wave of acquisitions was very different from the "hostile" takeover wave of the 1980s, when many acquirers were financiers, and the medium of payment was often cash rather than stock. These acquisitions also differed from the "conglomerate" wave in the 1960s, when mergers typically involved firms from different industries. At the same time, the waves of the 1960s and 1990s were similar in that the medium of payment was generally stock and both occurred during periods of very high stock market valuations. In the $1980 \mathrm{~s}$, in contrast, the valuations were lower.

Neoclassical theory sees mergers as an efficiency-improving response to various industry shocks, such as antitrust policy or deregulation (Mitchell and Mulherin, 1996; Jovanovic and Rousseau, 2002). In the conglomerate mergers of the 1960s, well-managed bidders built up diversified groups by adding capital and know-how to the targets (Gort, 1962; Rumelt, 1974; Meeks, 1977; Steiner, 1975). In the bust-up takeovers of the 1980s, raiders financed by bank debt and junk bonds acquired and split up the very same conglomerates assembled in the 1960s, because the conglomerate organization was no longer efficient (Jensen, 1986; Blair, 1993; Bhagat, Shleifer, and Vishny, 1990). The wave of related acquisitions in the 1990s, which still does not have a name, was part consolidation of major industries, and part response to deregulation (Holmstrom and Kaplan, 2001; Andrade et al., 2001).

The neoclassical theory of mergers has considerable explanatory power, but it is incomplete. Because it focuses on industry-specific shocks, it does not explain aggregate merger 
waves unless, of course, several industries experience shocks at the same time. The neoclassical theory also does not explain whether cash or stock is used to pay target shareholders, even though there are distinct patterns in the data on means of payment in mergers. On the central prediction of the neoclassical theory that mergers increase profitability, the evidence is inconclusive. Ravenscraft and Scherer (1987), focusing on the period of conglomerate mergers, fail to find evidence of improvements in profitability, whereas Healy, Palepu, and Ruback (1992), focusing on the period of hostile takeovers, do find such evidence.

Last but not least, the neoclassical theory is difficult to reconcile with some stock market evidence. Loughran and Vijh (1997) find that the market does not react correctly to the news of a merger, with acquirers making cash tender offers earning positive long-run abnormal returns, and those making stock acquisitions earning negative long-run abnormal returns. Rau and Vermaelen (1998) show that this pattern of returns remains even after the correction for size and book-to-market ratio recommended by Fama and French (1993). Mitchell and Stafford (2000) and Andrade et al. (2001), however, challenge this evidence on the grounds that merger observations are not statistically independent, and present long-run bidder returns that are lower in absolute value and statistically insignificant.

We propose a theory of acquisitions related to the neoclassical theory, but also able to accommodate the additional evidence. In this theory, transactions are driven by stock market valuations of the merging firms. The fundamental assumption of the model is that financial markets are inefficient, so some firms are valued incorrectly. In contrast, managers are completely rational, understand stock market inefficiencies, and take advantage of them, in part through merger decisions. Mergers in this model are a form of arbitrage by rational managers 
operating in inefficient markets. This theory is in a way the opposite of Roll's (1986) hubris hypothesis of corporate takeovers, in which financial markets are rational, but corporate managers are not. In our theory, managers rationally respond to less-than-rational markets. ${ }^{1}$

Our theory helps explain who acquires whom, the choice of the medium of payment, the valuation consequences of mergers, and merger waves. We show that the key ingredients of the answers are the relative valuations of the combining firms and the synergies that the market perceives in the merger. Our simple model is consistent with the available evidence, and yields several new predictions, including the following: 1) acquisitions are disproportionately for stock when aggregate or industry valuations are high, and for cash when they are low; 2) the volume of stock acquisition increases with the dispersion of valuations among firms; 3) targets in cash acquisitions earn low prior returns, whereas bidders in stock acquisitions earn high prior returns; 4) bidders in stock acquisitions exhibit signs of overvaluation, such as earnings manipulation and insider selling; 5) long-run returns to bidders are likely to be negative in stock acquisitions, and positive in cash acquisitions; 6) despite negative long-run returns, acquisitions for stock serve the interest of long-term shareholders of the bidder; 7) acquiring a firm in another industry may yield higher long-run returns than a related acquisition; 8) management resistance to some cash tender offers is in the interest of shareholders; 9) managers of targets in stock acquisitions are

${ }^{1}$ The idea that stock market valuations shape merger activity dates back at least to Nelson's (1959) study of merger waves in the U.S.: "It appears that merger expansion was not only a phenomenon of prosperity, but that it was also closely related to the state of the capital market. Two reference cycle expansions, unaccompanied by a strong upswing in stock prices, were marked by the absence of a merger revival." Our theory is part of the growing body of research on behavioral corporate finance, including Stein $(1988,1989,1996)$, Morck et al (1990a), Shleifer and Vishny (1990), Baker and Wurgler (2000, 2002a, 2002b), Baker, Stein and Wurgler (2003), Jenter (2002), and Polk and Sapienza (2002), which sees corporate financial policies as a response to market misvaluations. 
likely to have relatively short horizons or, alternatively, get paid for agreeing to the deal. Some of these predictions, such as the second and third, also follow from the neoclassical theory; others are more distinctive.

In Sections 2, 3, and 4, we present a simple model. Section 5 discusses the evidence. Section 6 concludes.

\section{A simple model of acquisitions}

We consider two firms, 0 and 1, with capital stocks $\mathrm{K}$ and $\mathrm{K}_{1}$, and stock market valuations per unit of capital of $\mathrm{Q}$ and $\mathrm{Q}_{1}$. We assume that $\mathrm{Q}$ and $\mathrm{Q}_{1}$ are not efficient valuations of these firms, but rather reflect investor sentiment about them. We do not model the sources of market inefficiency explicitly, relying on a growing theoretical and empirical literature describing the circumstances under which security prices deviate from fundamental values (Shleifer, 2000). Without loss of generality, we assume that $\mathrm{Q}_{1}>\mathrm{Q}$.

The investor sentiment affecting valuations can but need not be idiosyncratic: it may reflect over- or undervaluations of entire industries, sectors, or groups of firms with similar characteristics. For example, all diversified firms (conglomerates) can be in or out of favor, as can all technology stocks, all basic industry stocks, or all European stocks.

If the two firms merge, the short-run valuation of the combined equity per unit of capital is denoted by $\mathrm{S}$, so the market value of the two firms together is $\mathrm{V}=\mathrm{S}\left(\mathrm{K}+\mathrm{K}_{1}\right)$. We call $\mathrm{S}$ the "perceived synergy" of the merger. In effect, $\mathrm{S}$ is the story that the market consensus holds about the benefits of the merger. It could be a story about industrial diversification, or consolidation, or European integration. For example, $\mathrm{S}$ could be high when the market favors 
diversification and the two firms come from different industries. Alternatively, $\mathrm{S}$ could be high when a well-performing firm (high $\mathrm{Q}_{1}$ ) merges with a poorly performing firm (low Q). Lang, Stulz, and Walkling (1989) find that short-run announcement returns are consistent with the latter scenario. In our model, $\mathrm{S}$ is just the lubricant that greases the wheels of the M\&A process -- it might be invented by investment bankers or academics and have little to do with the reality of what drives actual acquisitions.

The case $\mathrm{S}=\mathrm{Q}$ corresponds to the market valuing the combination at the same value per unit of capital as the less valuable firm, and $\mathrm{S}=\mathrm{Q}_{1}$ to the market valuing the combination as the more valuable firm. It is possible that $\mathrm{S}>\mathrm{Q}_{1}$, in which case the combination of the two firms is perceived by the "euphoric" market to be more valuable (again, per unit of capital) than even the more valuable firm is on its own. It is also possible that $\mathrm{S}<\mathrm{Q}$, although we are unlikely to see mergers in this case (since, as we show below, both short- and long-run bidder returns are negative). We think that typically $\mathrm{Q}<\mathrm{S}<\mathrm{Q}_{1}$. Under these assumptions, the total short-run gains from two firms merging are given by $\mathrm{S}\left(\mathrm{K}+\mathrm{K}_{1}\right)-\mathrm{KQ}-\mathrm{K}_{1} \mathrm{Q}_{1}$. We call the synergy level $\mathrm{S}^{*}$ at which $\mathrm{S}^{*}\left(\mathrm{~K}+\mathrm{K}_{1}\right)-\mathrm{KQ}-\mathrm{K}_{1} \mathrm{Q}_{1}=0$ the no-synergy point. For $\mathrm{S}>\mathrm{S}^{*}$, there is a positive perceived synergy and the combined short-run return is positive.

We make the extreme assumption that, in the long run, all assets are worth q per unit of capital ( $\mathrm{q}$ is best thought of as the cost of capital). In the long run, then, firm 0 is worth $\mathrm{qK}$ as a stand-alone entity, firm 1 is worth $\mathrm{qK}_{1}$, and the combination, if it materializes, is worth $\mathrm{q}(\mathrm{K}+$ $\mathrm{K}_{1}$ ). This assumption implies that there are no long-run gains from a merger (regardless of whether cash or stock is used): no synergies in combining the two firms, and no managerial improvements. 
This specification allows for the maximum contrast between ours and the neoclassical theory of mergers (Mitchell and Mulherin, 1996). This is not to suggest that, empirically, mergers are always pure financial plays that create no long-run value. The wave of hostile takeovers in the 1980s has almost surely created efficiency gains (Jensen, 1986). In contrast, the wave of acquisitions in the 1990s might have destroyed value (Fuller and Jensen, 2002). In general, there is a great deal of doubt, especially outside the period of hostile takeovers, that mergers increase profitability (Meeks, 1977; Ravenscraft and Scherer, 1987; but see Healy, Palepu and Ruback, 1992, for the period 1979-1984). We make the stark simplifying assumption that mergers have no long-run real consequences to see how far it takes us.

Whereas we assume that the stock market is inefficient, managers are perfectly rational and informed. They know precisely with respect to both their own firms and the prospective merger partners how the short-run valuation deviates from efficiency, what the perception of synergies is, and what the long-run valuation will be. They then maximize their personal wealth given their horizons and their knowledge of market inefficiencies.

\section{The arithmetics of returns}

We consider first the more valuable firm 1 acquiring the less valuable firm 0 , and examine the consequences of this acquisition for both long- and short-term shareholders of the target and the acquirer, depending on whether the means of payment is cash or stock. Rather than adopt a specific model of takeover bids, such as Grossman and Hart (1980), we assume that the acquirer pays a price $\mathrm{P}$ per unit of capital of the target. We interpret $\mathrm{P}$ as the relative bargaining strength of the lower-valuation firm. Thus if $\mathrm{P}=\mathrm{Q}$, there is no takeover premium. If 
$\mathrm{P}=\mathrm{S}$, the price reflects the merged short-run valuation of the combined entity. We assume that $\mathrm{P}$ in many instances is lower than $\mathrm{S}$ because there are many potential targets around and, moreover, acquirers can compensate target managers personally for agreeing to merge at $\mathrm{P}<\mathrm{S}$.

We make the simplifying assumption that, aside from having a theory of perceived synergy, the market draws no inferences from the announcement of an acquisition. The announcement does not cause prices to converge to long-term values, or to move in that direction. Put differently, neither the merger itself, nor the choice of cash versus stock, conveys any information about management's valuation of assets in place (Myers and Majluf, 1984) or the severity of any agency problems (Morck et al., 1990b). Market beliefs are specified completely by $\mathrm{Q}, \mathrm{Q}_{1}$, and $\mathrm{S}$, and traders stick to these beliefs in the short run.

Except for simplicity, we do not need to assume no learning by the market. All that is necessary is that learning be incomplete, and the adjustment to rational valuations from the announcement of a merger or a security issue be partial. The conclusion that, in equilibrium, the market puts some weight on the beliefs of rational investors and some on investor sentiment is standard in models of inefficient markets (e.g., De Long et al.,1990). As long as investor sentiment influences prices, the results we obtain survive.

Consider first short-run gains to acquisitions (in terms of dollar amounts rather than percentages). In the short run, since there is no information entering the market other than the news of the merger, observed returns are due entirely to this news. Moreover, since the market draws the same inferences from acquisitions for cash and for stock, it is obvious that the bidder, the target, and the total short-run changes in value are invariant to whether the means of payment is cash or stock. We trivially establish the following proposition. 
Proposition 1. The immediate effect of the acquisition on the combined market value is

$\mathrm{S}\left(\mathrm{K}+\mathrm{K}_{1}\right)-\mathrm{K}_{1} \mathrm{Q}_{1}-\mathrm{KQ}$

the immediate effect on the short-run target value is

$(\mathrm{P}-\mathrm{Q}) \mathrm{K}$

and the immediate effect on the short-run bidder value is

$(\mathrm{S}-\mathrm{P}) \mathrm{K}+\left(\mathrm{S}-\mathrm{Q}_{1}\right) \mathrm{K}_{1}$.

In the short run, the combined entity benefits from the perception that the combination of the two firms is synergistic, in that some of the value of the more valuable one spills over on the less valuable one. Eq. (2) shows that P governs how much of that gain in the short run accrues to the target firm. When $\mathrm{P}=\mathrm{Q}$, target shareholders do not gain; when $\mathrm{P}=\mathrm{S}$, they gain proportionately to their capital. Finally, Eq. (3) shows that, in the short run, bidding shareholders gain insofar as they pay $\mathrm{P}<\mathrm{S}$ for the target and thus collect some of the gains from its higher valuation, but lose insofar as the valuation of their own capital is diluted from $Q_{1}$ to $S$.

This analysis suggests that at least some takeover activity is driven purely by short-run stock market perceptions. When $\mathrm{S}>\mathrm{Q}_{1}$, there is a money machine available to the bidding firm, which can buy assets and get its own capital revalued upwards. Presumably, such opportunities are limited. Even if the market is not euphoric, but believes in positive synergies $\left(S>S^{*}\right)$ from a merger, both the target and the acquirer could gain in the short run.

The results for the long-run valuation consequences of mergers are more interesting. Here we treat acquisitions for cash and stock separately. The results for cash are summarized in the following proposition. 
Proposition 2: The long-run effect of a cash acquisition on the combined value of the two firms is zero, the effect on the value of the target is $\mathrm{K}(\mathrm{P}-\mathrm{q})$, and the effect on the value of the acquirer is $\mathrm{K}(\mathrm{q}-\mathrm{P})$.

By construction, there are no long-term profitability gains from making acquisitions. What the target gains, the bidder loses. The only long-run reason for making acquisitions for cash is the undervaluation of the target. It is still likely that, if the bidder is overvalued, its preferred medium of payment for an undervalued target is stock. This choice, as we show below, depends on P relative to S. In this model, the target's undervaluation is a necessary, but not a sufficient, condition for cash deals.

Proposition 2 raises two related questions. Why does not a cash acquirer simply buy a diversified portfolio of undervalued firms? First, the acquirer may know a lot about a particular target, and would have more confidence about its undervaluation than that of a portfolio. Second, the realization of gains from undervaluation might require taking actions, such as a bustup and a sale of divisions, for which gaining control is necessary. A related question is why the acquirer's manager does not simply get into the business of buying undervalued assets, and give up the business of managing the firm. The answer is that we actually saw in the 1980s so-called raiders, who specialized in acquiring and busting up undervalued firms. But one can also imagine the benefits of conducting such business through a company with a balance sheet, perhaps to make it easier to raise cash for acquisitions.

In our model, managers of takeover targets benefit their long-term shareholders by resisting tender offers at a premium if $\mathrm{Q}<\mathrm{P}<\mathrm{q}$. The interest of long-term shareholders is not just an excuse for resistance, as it has been portrayed in agency models. Shareholders actually 
benefit from resistance in the long run as share prices return to fundamentals, even though prices decline in the short run when offers are turned down.

In the case of acquisitions for stock, the share $\mathrm{x}$ of the combined firm's equity that the target shareholders end up owning after the exchange of shares is given by $\mathrm{x}=\mathrm{PK} /\left[\mathrm{S}\left(\mathrm{K}+\mathrm{K}_{1}\right)\right]$.

In the long run, this share is worth $\mathrm{xq}\left(\mathrm{K}+\mathrm{K}_{1}\right)=\mathrm{q}(\mathrm{P} / \mathrm{S}) \mathrm{K}$. We can establish the following proposition.

Proposition 3: The net long-run gain to the shareholders of the target firm from being acquired for stock is $\mathrm{q}(\mathrm{P} / \mathrm{S}) \mathrm{K}-\mathrm{qK}=\mathrm{qK}(\mathrm{P} / \mathrm{S}-1)$, and that to the bidding shareholders is the opposite, i.e., $\mathrm{qK}(1-\mathrm{P} / \mathrm{S})$.

In the long run, bidding shareholders gain if and only if $\mathrm{P}<\mathrm{S}$, i.e., shares are exchanged on terms better (from bidder viewpoint) than the market's short-run assessment of synergy. Bidders can only benefit if they increase their shareholders' claim on physical capital, which happens when $\mathrm{P}<\mathrm{S}$. Since all capital is worth the same in the long run, they end up better off. When the price is below the blended short-run valuation of the two companies, bidding shareholders redistribute wealth away from the target shareholders to themselves.

In this model, there is an important difference between the effect of an acquisition on the long-run value and the observed long-run returns. The acquirer's long-run returns without making an acquisition would have been $\mathrm{K}_{1}\left(\mathrm{q}-\mathrm{Q}_{1}\right)$, which is negative when the firm is initially overpriced. The acquirer's long run incremental return from making the acquisition is given by $\mathrm{qK}(1-\mathrm{P} / \mathrm{S})$, which is positive when $\mathrm{P}<\mathrm{S}$. The total observed return may still be negative, especially if initial overvaluation is significant, but this does not mean that the acquisition does 
not serve the interest of the bidding shareholders. Indeed, when $\mathrm{P}<\mathrm{S}$, bidding shareholders gain in the long run even when the observed stock returns are negative: returns are just not as negative as they would have been without the acquisition.

This distinction between long-run gains from a stock merger and observed long-run returns raises a number of interesting possibilities. To begin, it may be in the long-term, but not the short-term, interest of shareholders of firm 1 to acquire firm 0 . When $\mathrm{P}<\mathrm{S}$ but $(\mathrm{S}-\mathrm{P}) \mathrm{K}+(\mathrm{S}-$ $\left.\mathrm{Q}_{1}\right) \mathrm{K}_{1}<0$, the shares of firm 1 drop on the announcement of the deal, but the acquisition still benefits its long-run shareholders because in the long run the shares would have fallen even more. Indeed, both short- and long-run observed returns in this range may be negative, but the acquisition still serves the interest of the long-term shareholders of the acquirer. Using overvalued shares as a means of payment enhances the claim on capital of the bidding shareholders, and thereby cushions the collapse of the shares in the long run.

\section{Discussion}

Why would a firm make an acquisition for stock, rather than just issue equity and invest in either cash or its own business? To address this question, we need to consider the long-run payoffs to the three alternative strategies. For all three strategies, we make the same simplifying assumption that the market learns nothing from the firm's issuance decision, contrary to Myers and Majluf (1984). We also assume that investors know exactly how the issuer will use the

funds raised in an equity issuance; the management cannot trick investors by changing the way it uses funds.

Conceptually, acquisitions for stock and greenfield investment financed by equity issues 
are identical. Compare the acquisition of $\mathrm{K}$ units of capital at a price $\mathrm{P}$ per unit with an investment of K units of capital acquired at a price R per unit. Suppose that both are equity financed, and that the former results in a valuation of the combined firm of S per unit of capital, while the latter results in the post-issuance valuation of $\mathrm{T}$ per unit of capital. We have shown before that the acquisition serves the interest of acquirer shareholders as long as $\mathrm{P}<\mathrm{S}$.

Likewise, the share issuance financed investment serves the interest of long-term shareholders as long as $\mathrm{R}<\mathrm{T}$. It is trivial to show that acquisition is more likely to be preferred to investment the lower is $P$ relative to $R$, and the higher is $S$ relative to $T$.

When is this likely to occur? Generally speaking, new capital probably costs less than whole firms $(\mathrm{R}<\mathrm{P})$, unless there are significant bottlenecks in the capital goods industry that make is cheaper to buy old capital than to install new capital. It is more likely, however, that $\mathrm{S}>$ T. This would happen, for example, if a high-valuation firm has enough capacity to meet the market demand for its existing product, so market participants believe that it can only grow by extending its product line. In this case, the valuation of new investment is low, but a perceived synergy from an acquisition is higher. The bottom line is that investing is not necessarily better than making acquisitions, and in equilibrium we expect to see some of each. How far additional investment or acquisitions will go depends, of course, on how fast $\mathrm{S}$ and $\mathrm{T}$ fall relative to the costs with each additional transaction.

An extreme version of investing in capital that is cheaper than acquisitions in an overvalued market is issuing equity to hold cash. Assume again that the acquisition has synergy $\mathrm{S}$, and takes place at price $\mathrm{P}$, and compare this to raising PK by issuing equity and holding PK in cash. In this case, the condition that the acquisition is preferred by long-term shareholders is 


$$
\frac{S\left(K+K_{1}\right)-P K}{S\left(K+K_{1}\right)}\left[q\left(K+K_{1}\right)\right]>\frac{Q_{1} K_{1}}{P K+Q_{1} K_{1}}\left[P K+q K_{1}\right]
$$

In this case, it is still possible that an acquisition is better as long as $\mathrm{S}$ is high enough. One special case is that of a large share issuance for holding cash or making an acquisition, so we can take the limit as $\mathrm{K}_{1} / \mathrm{K}$ approaches zero. In this case, an acquisition is preferred as long as $\mathrm{S}>\mathrm{P}$, i.e., the perceived synergy is greater than the price paid for the target. This condition makes intuitive sense: since the perceived synergy applies to the valuation of the whole company, as long as it is higher than the price paid for the acquisition, the transfer of capital in the long run to the old shareholders is high enough to outweigh the benefits of a fair-priced investment in cash. The point here, as before, is that, with high enough perceived synergies, making acquisitions might be the best strategy for the shareholders of the bidding firm.

Issuing shares and investing in cash can also have an adverse signaling effect that leads to a reduction in $\mathrm{Q}_{1}$. This signaling effect is distinct from Myers and Majluf(1984) in that the signal comes from the investment policy rather than from capital structure. The advantage of making acquisitions, aside from the positive perceived synergies, is that they contribute to the growth in earnings of the firm, and thereby help justify the high valuations. As the policies of Cisco and other technology firms illustrate, acquisitions become part of a growth strategy justifying high market multiples in a way that cash accumulation cannot. For this reason as well, it might be better to use overvalued equity to buy other overvalued firms than to invest in cash. A second important question is why would the target agree to a stock merger? In this model, combined long-run benefits of an acquisition are always zero, so what the bidder gains 
the target loses. If the bidder acts in the interest of its long-term shareholders by making the acquisition, the target must be hurting its long-term shareholders by consenting to it. Put differently, who would agree to be a target?

We can think of two related answers. The first concerns the difference in the horizons of the various managers (see Stein, 1988, 1989; Shleifer and Vishny, 1990). If $\mathrm{Q}<\mathrm{P}<\mathrm{S}$, then target shareholders gain in the short-run but lose in the long run. Bidder shareholders, in contrast, might lose in the short-run, but gain in the long run. Target shareholders receive a premium, and as long as they sell the shares they obtain in the exchange, they are better off. The acquirer shareholders (or their management), who for whatever reason keep their shares, benefit in the long run if $\mathrm{P}<\mathrm{S}$. The losers are those holding onto shares in an overvalued market.

Under this view, we expect target firms to be those whose managers want to "sell out," for reasons of retirement or ownership of illiquid stock options. In contrast, we expect bidding firms to be controlled by shareholders who cannot as easily get out: irreplaceable executives with large equity stakes or managers who are young or locked in. The examples of family firms selling out to conglomerates in the 1960s and of entrepreneurial firms selling out to Cisco and Intel in the 1990s fit nicely with this view.

A second reason for target management's consent is that the acquirer pays them for it. This can be done through the acceleration in the exercise of stock options (which could be very valuable if the target is overvalued), severance pay, or even by keeping the managers of the target in top positions (as was done, for example, in the AOL acquisition of Time Warner). Both the target and the acquirer managers benefit: the former by cashing out or keeping a good job, the latter by increasing the long-run value of their equity. When target managers sell out, both 
they and the bidder managers in effect get rid of overvalued equity: one through a personal sale, the other through issuance. The absence of such gains from trade (at the expense of the new bidder shareholders) is precisely why we see more hostility in cash tender offers than in stock mergers. Consistent with this analysis, Hartzell, Ofek, and Yermack (2003) present compelling evidence that managers of target firms obtain significant wealth increases in acquisitions, and that those receiving extraordinary personal treatment agree to lower acquisition premia.

This analysis gives us a map of when we are likely to see acquisitions, and what kind. To begin, we expect targets of cash acquisitions to be undervalued firms, and moreover, we predict that such acquisitions are more likely to be hostile than those for stock. We are likely to see acquisitions for stock under a combination of three circumstances. First, market valuations must be high, and there must be a supply of highly overvalued firms (bidders) as well as of relatively less overvalued ones (targets). This condition is more likely to obtain when the dispersion of valuations in the market is also high. Second, the market should perceive a synergy, which makes the mergers relatively more attractive in the short-run, and enables the acquirers to pay a premium yet still enhance their long-run claim on capital. Third, either target managers have short-horizons, or alternatively they are paid off to consent to a merger.

Finally, we return to the possibility of firm 0 , the less valuable one, acquiring firm 1 . If we denote the price that firm 0 pays for firm 1 by $P$, we must have $P \$ Q_{1}$ for firm 1 to agree to a takeover. Since any bidder only benefits in the long run from an acquisition for cash if $\mathrm{P}<\mathrm{q}$, we could see such acquisitions when $\mathrm{Q}<\mathrm{Q}_{1}<\mathrm{P}<\mathrm{q}$, i.e., in a highly undervalued market. This is possible, and indeed we saw some such deals in the 1980s. However, such deals are likely to be limited because extreme undervaluation is probably temporary and, moreover, such low- 
valuation bidders might be unable to raise capital to finance acquisitions. The lower-valuation bidder benefits from an acquisition for stock if $\mathrm{P}<\mathrm{S}$, which means $\mathrm{S}>\mathrm{P}>\mathrm{Q}_{1}>\mathrm{Q}$. Such acquisitions require fantastic perceived synergies, which seem unlikely to materialize very often, especially when the lower-valuation firm rather than the high-flying firm assumes control.

\section{Implications}

In this section, we discuss the empirical implications of the analysis. We divide the discussion into three parts. First, we examine the theory in light of the available empirical evidence on short- and long-run stock returns. Second, we look at the relationship between the aggregate merger activity and the stock market by considering the three U.S. merger waves in the last 40 years. Third, we review some of the untested implications of the model.

\subsection{Implications for the cross-section of returns}

Recent evidence on long- and short-term stock returns around acquisition announcements is carefully summarized by Agrawal and Jaffe (2000) and Andrade et al. (2001) and we rely on their summaries of the evidence rather than on individual studies. Andrade et al. show that in a sample of 3,688 mergers between 1973 and 1998, target firms gain $23.8 \%$ in the window beginning 20 days before the acquisition announcement and ending on the close. Acquirer firms lose $3.8 \%$ over the same interval, and the combined value change is a statistically insignificant $1.9 \%$. If we translate the returns in the propositions into percentage returns rather than dollar amounts, our model can easily mimic this pattern of returns. In fact, the simple case of equalsized firms with $\mathrm{S}=\mathrm{P}=1.25, \mathrm{Q}=1$, and $\mathrm{Q}_{1}=1.3$ generates a $25 \%$ gain for the target firm, a $5 \%$ 
loss for the acquirer, and a $2.5 \%$ loss in the combined value.

The evidence on long-run returns is more interesting. Our model suggests that the more highly valued acquirer would only make a cash bid if the target is undervalued even at the bid price, i.e., $\mathrm{P}<\mathrm{q}$. This is most likely to happen with seriously undervalued targets, which must have experienced low returns prior to being acquired. The evidence on this is limited, although Schwert (2000) documents lower valuations of targets of hostile takeovers than of average targets, whereas Andrade et al. (2001) show that in 66\% of mergers between 1973 and 1998, the acquirer's Q exceeded the target's Q. More importantly, our model predicts that long-run bidder returns from cash acquisitions should be positive. Loughran and Vijh (1997) find that, after a size and book-to-market adjustment, tender offers result in positive abnormal bidder returns of $43 \%$ in the five years following the merger. Rau and Vermaelen (1998) use a larger sample of 316 tender offers between 1980 and 1991, and find that acquirers experience long-run excess returns of $8.5 \%$ in the three years following the merger. This evidence is supportive of our model.

The crucial case is of course acquisitions for stock. The model suggests that such acquisitions are made by overvalued acquirers of relatively less overvalued targets. Moreover, in the model, such acquisitions are likely to result in negative long-run returns, but -- as long as $\mathrm{P}<\mathrm{S}$-- not as negative as would have obtained without the acquisition. This prediction is consistent with Rau and Vermaelen (1998), who find that acquirers in mergers earn a statistically significant negative $4 \%$ return relative to a size and book-to-market benchmark in the three years 
after the merger. ${ }^{2}$ Agrawal and Jaffe (2000) list earlier papers corroborating this finding. Rau and Vermaelen also show that value bidders outperform glamour bidders in the three years after the completion of the merger, and that glamour bidders pay more frequently with stock than do value bidders. Both of these findings are consistent with our view that acquisitions completed with stock arise from the overvaluation of the bidder relative to the target. Acquisitions for stock by the glamour bidders indeed appear to be a defensive strategy we model.

Interestingly, the key studies of long-run bidder returns, such as Loughran and Vijh (1997), Rau and Vermaelen (1998), and Agrawal and Jaffe (2000), treat the two predictors of negative long-run bidder returns -- higher bidder valuation (measured in various ways) and the use of stock as a means of payment -- as evidence for two different hypotheses, which they call the method of payment hypothesis and the performance extrapolation hypothesis.

In our model, these results are part of the same story. The performance extrapolation hypothesis states that the market wrongly extrapolates the past performance of the bidder in determining the combined value of the two firms. This corresponds to positive synergy in our model. According to the means of payment hypothesis, if managers are better informed about the firm's prospects than the market, they acquire with stock when stock is overpriced, and use cash otherwise. In our model, both the decision to acquire and the means of payment derive from market timing. Stock acquisitions are used specifically by overvalued bidders who expect to see negative long-run returns on their shares, but are attempting to make these returns less

${ }^{2}$ Strictly speaking, this statement is only true when bidders in stock acquisitions are overvalued even relative to their book-to-market benchmark, which is plausible. As noted in the introduction, there is also a statistical controversy over this evidence (Mitchell and Stafford, 2000). 
negative. In these acquisitions for stock, a high level of perceived synergy can be essential because the condition for both short- and long-run attractiveness for the bidder is $\mathrm{P}<\mathrm{S}$. Even if such synergies do not exist, there is a strong incentive to "invent" them.

\subsection{Merger waves}

In his original study, Nelson (1959) pointed out that mergers are highly concentrated in time, that they cluster during periods of high stock market valuations, and that the means of payment is generally stock. Andrade et al. (2001) confirm this picture but also show that the preponderance of stock acquisitions is greater in high-valuation markets, consistent with our model. Thus acquisitions where any stock was used as payment represent $45.6 \%$ of total in the 1980 s, versus $70.9 \%$ in the $1990 \mathrm{~s}$. The share of acquisitions that were all for stock rose from $32.9 \%$ in the 1980 s to $57.8 \%$ in the 1990 s. Verter (2002) presents systematic evidence of higher levels of merger activity in higher-valuation markets. He also finds, consistent with the model, that 1) this correlation is driven by acquisitions for stock, 2) a high incidence of acquisitions for stock predicts low subsequent market returns, suggesting overvaluation, and 3) high levels of merger activity are associated with a higher dispersion in valuations.

We can use the model to say a bit more about the American M\&A experience of the last 40 years. In our framework, the conglomerate merger wave of the 1960s is the case of prototypical acquisitions by the more overvalued firms of the less overvalued ones for stock. A commonly given reason why these acquisitions took the form of diversification is that the antitrust policy restricted related acquisitions (e.g., Shleifer and Vishny, 1991). Our model suggests a different reason. For long-term shareholders of high-valuation bidders, it might have 
been advantageous to issue new stock to diversify and to build conglomerates so as to raise their claim to long-term capital. Such acquisitions might have been more attractive than those in the same industry because within-industry target valuations were too high to justify acquisitions, even when perceived synergies were higher than those for diversification. All that was required was a good story, S, for the benefits of diversification.

Conveniently, such a story was invented: the efficiency gains from conglomeration through better management. Thanks to this story, positive short-run returns accrued to both the acquirers and the targets (Matsusaka, 1990). Moreover, even though conglomerates have not increased profits (Ravenscraft and Scherer, 1987), and the long-run stock market returns to the acquirers have been negative (Agrawal and Jaffe, 2000), such acquisitions were still preferable to doing nothing. In our model, negative bidder returns are not evidence of a failure to serve shareholder interests -- conglomerate values would have fallen even more without them.

The acquisition of smaller family firms by conglomerates such as ITT, and the vertical integration of franchisee-owned restaurants by McDonald's, illustrate this logic. In our model, because the targets were so much smaller than the acquirers, we can think of conglomeration as diversification with $S=Q_{1}$. Indeed, discussions of the 1960s acquisitions often argue that the purpose of these combinations was to transfer the high multiple of the acquirer to the earnings of the target. From this angle, the focus on efficiency aspects of conglomerates in most discussions of the 1960s is just window dressing; the fundamental economics have to do with buying hard capital using overvalued shares. A final point has to do with horizons. The targets in conglomerate mergers were often family-run firms, whose owners wished to sell out and retire. This is exactly what the model predicts: a merger requires a coincidence of short-term objectives 
of the target managers with longer-run objectives of the bidders.

In the 1980 s, following a decade of miserable stock market performance, the market saw a wave of bust-up takeovers. As our model predicts, these were likely to target undervalued firms, and to take place for cash rather than stock. Moreover, the incidence of hostility was higher in the 1980s than in any other major merger wave -- as the model predicts for takeovers of low-valuation firms for cash. The common finding that the bust-up value of the acquired firms was higher than the acquisition price is broadly consistent with our view that market undervaluation of targets was central to the 1980s takeovers (Kaplan, 1989; Bhagat et al., 1990). Also consistent with the model, the 1980s acquisitions were not followed by negative long-run acquirer returns, unlike the acquisitions from the earlier period.

Some other aspects of the 1980 s takeover wave also fit the model. The model implies that, for these acquisitions to earn good short-run returns for acquiring shareholders, a story of perceived synergy, or of benefits to the valuation of combined firms, is needed. It is possible that the free cash flow theory of Jensen (1986), with its emphasis on the elimination of agency problems through takeovers, provided the necessary story for that period. Our model also provides an alternative interpretation of why the takeover wave of the 1980s petered out toward the end of that decade. The traditional explanation is that corporate, state, and federal antitakeover policies, as well as legal action against Drexel and other financiers of hostile deals, raised the costs of takeover bids to acquirers to the point that the activity was no longer profitable. In our model, in contrast, the more important culprit is the rising stock market prices, which eliminated undervaluation -- the fundamental reason for the takeover wave of the 1980s. Like the conglomerate merger wave of the 1960s, the 1980s wave fits nicely into our framework. 
The rising stock market valuations of the 1990s, particularly the second half, stimulated another massive takeover wave. The acquisitions were generally for stock, and the acquirers were often more highly valued firms than the targets, even when both belonged to the same industry. The story of perceived synergies changed to a combination of technological synergies, industry consolidation, and European integration, although in some instances the spin did not rescue the short-run acquirer returns.

A classic merger of this period is the acquisition of Time Warner by America Online for stock (although in this instance, S was not as high as AOL management hoped: the company lost a third of its market value in the few months following the announcement). ${ }^{3}$ From our perspective, the central feature of this acquisition is not technological synergies, but rather the attempt by the management of overvalued AOL to buy the hard assets of Time Warner to avoid even worse returns in the long run. In this acquisition, as in other deals involving hightechnology acquirers with overvalued stock prices, long-run acquirer returns appear to be poor. However, according to our model, these returns are not as negative as they would have been had the acquisitions not taken place. When future writers condemn the merger spree of the late 1990s as manifesting misguided policies on the part of the acquirers, they should focus on the alternative of not making these acquisitions. Indeed, the fact that many of the high-tech acquirers during this period were entrepreneurial firms, with managers owning substantial equity stakes, is prima facie evidence that the motive for these acquisitions was not agency, but overvaluation.

${ }^{3}$ This material was originally written in 2000, before the AOL Time Warner merger publicly became recognized as a disaster for the shareholders of Time Warner who kept the AOL stock. 


\subsection{Untested predictions}

Before concluding this section, we reiterate three very distinctive predictions of the model that have not yet been tested directly, but which are testable.

First, the model predicts that targets in cash acquisitions are undervalued in absolute terms (i.e., relative to fundamentals), but targets in stock acquisitions are undervalued relative to the bidders. A corollary of this prediction is that the pace of stock mergers should be higher in industries and markets with a large dispersion of valuations.

Second, bidders in stock acquisitions should exhibit signs of overvaluation relative to fundamentals. Recent research proposes several measures of overvaluation, including abnormally high insider sales, earnings manipulation through accruals, and negative postformation returns (Jenter, 2002; Polk and Sapienza, 2002; Baker, Stein and Wurgler, 2003). Erickson and Wang (1999) actually find that, between 1985 and 1990, acquiring firms in stock deals managed earnings prior to merger agreement so as to raise their stock prices. It remains to be tested more systematically whether acquirers in stock deals exhibit signs of overvaluation.

Third, the model makes a prediction that bidders in stock acquisitions either have relatively longer horizons than those of the targets, or alternatively pay off target managers to agree to the stock merger. Since horizons of corporate managers can be measured using data on age or stock options, and data on the personal deals that target managers get are also available (Hartzell, Ofek, and Yermack, 2003), this prediction is testable.

\section{Conclusion}

This paper has presented a model of stock-market-driven acquisitions. It falls into the 
rapidly growing field of behavioral corporate finance, which sees corporate policies such as debt and equity issuance, share repurchases, dividends, and investment as a response to market mispricing. A good deal of empirical evidence appears to be consistent with this view.

Our model takes mispricing as given. But it also points to a powerful incentive for firms to get their equity overvalued, so that they can make acquisitions with stock. In a more general framework, firms with overvalued equity might be able to make acquisitions, survive, and grow, while firms with undervalued, or relatively less overvalued, equity become takeover targets themselves. ${ }^{4}$ The benefit of having a high valuation for making acquisitions also points to an incentive to raise a firm's stock price even through earnings manipulation, a phenomenon whose prevalence is becoming increasingly apparent (D'Avolio et al., 2001).

This model is not intended to deny a role for real rather than just valuation factors, noted in recent surveys by Holmstrom and Kaplan (2001) and Andrade et al. (2001). Still, the model helps interpret a good deal of evidence, and yields new predictions. As such, it may add to the set of frameworks that financial economists use to examine mergers and acquisitions.

\footnotetext{
${ }^{4} \mathrm{~A}$ recent article in the New York Times notes, in line with this reasoning, that Deutsche Bank might not survive as an independent entity because its valuation is much lower than that of its competitors, and that it is making efforts to raise its valuation both to survive and to make acquisitions for stock (Andrews, 2002).
} 


\section{References}

Agrawal, A., Jeffrey, J., 2000. The post-merger performance puzzle. In Advances in Mergers and Acquisitions 1, 7-41, Elsevier Science, Amsterdam.

Andrade, G., Mitchell, M., Stafford, E., 2001. New evidence and perspectives on mergers? Journal of Economic Perspectives 15, 103-120.

Andrews, E., 2002. Becoming less German, New York Times, Section C, p. 1, May 21.

Baker, M., Stein, J., Wurgler, J., 2003, When does the market matter? Stock prices and the investment of equity-dependent firms, Quarterly Journal of Economics, forthcoming.

Baker, M., Wurgler, J., 2000. The equity share in new issues and aggregate stock returns. Journal of Finance 55, 2219-2258.

Baker, M., Wurgler, J., 2002a. Market timing and capital structure. Journal of Finance 57, 1-32.

Baker, M., Wurgler, J., 2002b. A catering theory of dividends, Unpublished working paper. Harvard Business School, Boston.

Bhagat, S., Shleifer, A., Vishny, R., 1990. Hostile takeovers in the 1980s: the return to corporate specialization. Brookings Papers on Economic Activity: Microeconomics, 1-72.

Blair, M., 1993. The deal decade: what takeovers and leveraged buyouts mean for Corporate governance. Brookings Institution, Washington.

D’Avolio, G., Gildor, E., Shleifer, A., 2001. Technology, information production, and market efficiency. In Federal Reserve Bank of Kansas City, Economic policy and the information economy.

DeLong, B., Shleifer, A., Summers, L., Waldmann, R., 1990a. Noise trader risk in financial markets. Journal of Political Economy 98, 703-738. 
Erickson, M.,Wang, S., 1999. Earnings management by acquiring firms in stock for stock acquisitions. Journal of Accounting and Economics 27, 149-176.

Fama, E., French, K., 1993. Common risk factors in the returns on stock and bonds. Journal of Financial Economics 33, 3-56.

Fuller, J., Jensen, M., 2002. Just say no to Wall Street. Journal of Applied Corporate Finance 14, $41-46$.

Gort, M., 1962. Diversification and integration in American industry. Princeton University Press: Princeton.

Grossman, S., Hart, O., 1980. Takeover bids, the free rider problem, and the theory of the corporation. Bell Journal of Economics 11, 42-64.

Hartzell, J., Ofek, E., Yermack, D., 2003. What's in it for me? CEOs whose firms are acquired. Review of Financial Studies, forthcoming.

Healy, P., Palepu, K., Ruback, R., 1992. Does corporate performance improve after mergers? Journal of Financial Economics 31, 135-176.

Holmstrom, B., Kaplan, S., 2001. Corporate governance and merger activity in the U.S.: making sense of the 80's and the 90's. Journal of Economic Perspectives 15, 121-144.

Jensen, M., 1986. Agency cost of free cash flow, corporate finance and takeovers. American Economic Review Papers and Proceedings 76, 323-329.

Jenter, D., 2002. Market timing and managerial portfolio decisions. Unpublished working paper. Harvard University.

Jovanovic, B., Rousseau, P., 2002. The q-theory of mergers. American Economic Review Papers and Proceedings 92, 198-204. 
Kaplan, S., 1989. The effects of management buyouts on operating performance and value. Journal of Financial Economics 24, 217-254.

Lang, L., Stulz, R., Walkling, R., 1989. Managerial performance, Tobin's q, and the gains from successful tender offers. Journal of Financial Economics 24, 137-154.

Loughran, T., Vijh, A., 1997. Do long-term shareholders benefit from corporate acquisitions? Journal of Finance 52, 1765-1790.

Matsusaka, J., 1990. Takeover motives during the conglomerate merger wave. Unpublished working paper. University of Chicago.

Meeks, G., 1977. Disappointing marriage: a study of the gains of the merger. University of Cambridge Occasional Paper 51, Cambridge University Press, Cambridge.

Mitchell, M., Mulherin, H., 1996. The impact of industry shocks on takeover and restructuring activity. Journal of Financial Economics 41, 193-230.

Mitchell, M., Stafford, E., 2000. Managerial decisions and long term stock price performance. Journal of Business 73, 287-329.

Morck, R., Shleifer, A., Vishny, R., 1990a. The stock market and investment: is the market a sideshow? Brookings Papers on Economic Activity, 157-215.

Morck, R., Shleifer, A., Vishny, R., 1990b. Do managerial objectives drive bad acquisitions? Journal of Finance 45, 31-48.

Myers, S., Majluf, N., 1984. Corporate financing and investment decisions when firms have information that investors do not have. Journal of Financial Economics 13, 187-221.

Nelson, R., 1959. Merger Movements in the American Industry. NBER, New York.

Polk, C., Sapienza, P., 2002. The real effects of investor sentiment. Unpublished working paper. 


\section{Kellogg Graduate School of Business.}

Rau, R., Vermaelen, T., 1998. Glamour, value, and the post-acquisition performance of acquiring firms. Journal of Financial Economics 49, 223-254.

Ravenscraft, D., Scherer, F., 1987. Mergers, selloffs, and economic efficiency. Brookings Institution, Washington.

Roll, R., 1986. The hubris hypothesis of corporate takeovers. Journal of Business 59, 197-216.

Rumelt, R., 1974. Strategy, structure, and economic performance. Harvard Business School Press: Boston.

Schwert, W., 2000. Hostility in takeovers: in the eye of the beholder? Journal of Finance 55, 2599-2640.

Shleifer, A., 2000. Inefficient markets: an introduction to behavioral finance. Oxford University Press, Oxford, U.K.

Shleifer, A., Vishny, R., 1990. Equilibrium short horizons of investors and firms. American Economic Review Papers and Proceedings 80, 148-153.

Shleifer, A., Vishny, R., 1991. Takeovers in the `60s and '80s: evidence and implications. Strategic Management Journal 12, 51-59.

Stein, J., 1988. Takeover threats and managerial myopia. Journal of Political Economy 96, 6180.

Stein, J., 1989. Efficient capital markets, inefficient firms: a model of myopic corporate behavior. Quarterly Journal of Economics 104, 655-669.

Stein, J., 1996. Rational capital budgeting in an irrational world. Journal of Business 69, 429455. 
Steiner, P., 1975. Mergers: motives, effects, policies. University of Michigan Press: Ann Arbor. Verter, G., 2002. Timing merger waves. Harvard University Mimeo. 